\title{
Factors Influencing Student Participation In College Study Abroad Programs
}

\author{
Soumava Bandyopadhyay, Lamar University, USA
}

Kakoli Bandyopadhyay, Lamar University, USA

\begin{abstract}
This paper proposes a theoretical framework to investigate the factors that influence student participation in college study abroad programs. The authors posit that students' general perceptions regarding the study abroad experience and their expectations of intercultural awareness from study abroad programs will impact their perceptions of personal growth, professional development, and intellectual growth to be derived from such programs. The expectations regarding personal growth, professional development, and intellectual growth will, in turn, directly impact students' intention to participate in such programs. Program duration, cost, and student demographics, such as race and gender are other influencing factors. Following the presentation of the framework, strategies to effectively market study abroad programs are discussed.
\end{abstract}

Keywords: Study Abroad; Higher Education; International Education; Intercultural Experience

\section{INTRODUCTION}

$\theta$ tudying abroad is an academic experience where college students physically leave the United States to engage in college study, cultural interaction, and other related pursuits in a foreign host country (McKeown, 2009). The benefits of participating in a study abroad program include increased multicultural awareness, greater foreign language proficiency, better professional and personal development, and better academic performance (Ingraham and Peterson, 2004; Hadis, 2005). Studying abroad is also expected to prepare students for active global citizenship, which would enable American students to strengthen international development efforts and enhance their country's image abroad (Tarrant, Rubin, and Stoner, 2014; Horn and Fry, 2013). Public policymakers have recognized the value of an international study experience. The Lincoln Commission (2005) has argued that study abroad experiences should be the norm in higher education, rather than the exception. The United States Senate designated the year 2006 as the "Year of Study Abroad" in acknowledging the role study abroad plays in shaping American education and global leadership (Zemach-Bersin, 2007).

As a result of the efforts to popularize study abroad programs, the number of American college students participating in such programs has been increasing steadily in recent years. The Open Doors Report from the Institute of International Education (2013) confirmed that 283, 332 American college students studied abroad in the year 2011-12, which was an increase of 7.1\% from the previous year. The number, though apparently impressive, represents only $1.4 \%$ of all higher education students in the U.S., however. This indicates that there is still a lot of room for growth in the participation of American college students in study abroad programs. One of the main challenges for university program directors is to get a high percentage of students to participate in study abroad programs to derive the benefits (Goldstein and Kim, 2006). The key would be to first identify the relevant factors that impact students' participation in study abroad programs. These factors would include students' expectations from participating in study abroad programs as well as practical constraints (expense, time, etc.). Next, the study abroad programs need to be marketed effectively based on the promise of fulfilling the expectations and alleviating the impediments.

In this paper, the authors propose a conceptual framework to explain the interrelationships among the factors that are likely to influence college students' decision to participate in study abroad programs. Studies 
reported so far (e.g., Ingraham and Peterson, 2004; de Jong, Schnusenberg, and Goel, 2010; Salisbury et al., 2009; Goldstein and Kim, 2006; Hembroff and Rusz, 1993; Carlson et al., 1990) have identified and discussed only a few subsets of all possible influencing factors. A model that includes a comprehensive set of factors is presented. An understanding of the interrelationships among these factors will help predict students' intentions to participate in study abroad programs. This would be a valuable tool for college advisors to increase the participation rates in these programs.

\section{THE FRAMEWORK}

The proposed framework is presented in Figure 1. Student participation in study abroad programs mainly depends on the students' expectations of specific benefits from such programs (Kim and Goldstein, 2005). General perceptions held by students about study abroad programs (such as relevance of the program in the degree plan, sightseeing, etc.) and the students' level of intercultural awareness (Bennett, 2004) will impact three types of expected benefits from study abroad programs: personal growth, professional development, and intellectual growth (Carlson et al., 1990; Ingraham and Peterson, 2004). The expectations regarding personal growth, professional development, and intellectual growth will, in turn, directly impact students' intention to participate in study abroad programs. The duration and cost of participating in study abroad programs (Naffziger, Bott, and Mueller, 2008), as well as certain demographic characteristics of students (Hembroff and Rusz, 1993), are also likely to directly impact the intention to participate. The variables in the framework are discussed in more detail next.

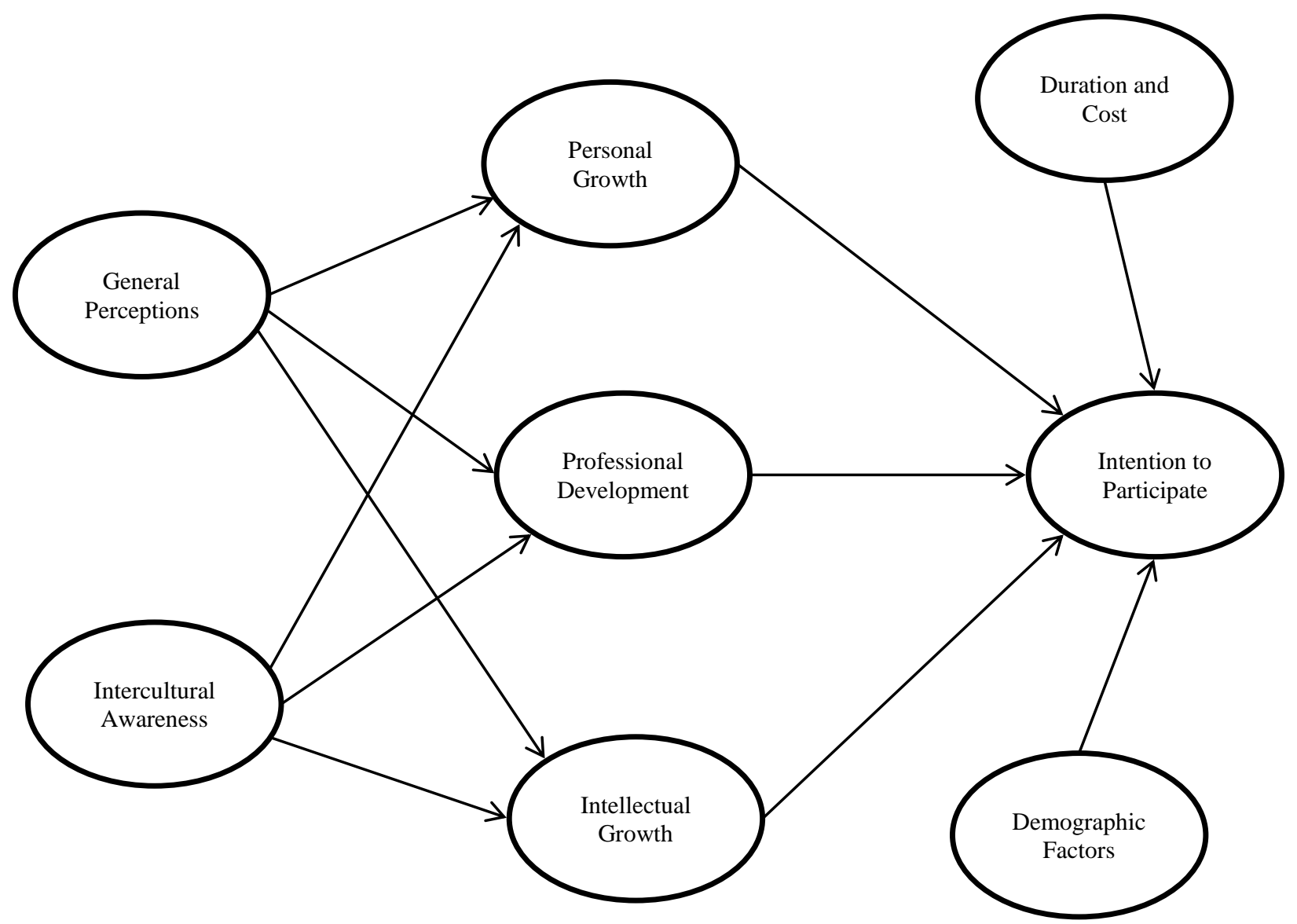

Figure 1: The Proposed Framework Of Factors Influencing Student Participation In Study Abroad Programs 


\section{General Perceptions}

Students' will have certain general perceptions regarding any study abroad program that they may consider participating in. Congruence of the study abroad program with the students' planned career path is an important consideration (Norris and Gillespie, 2009). Therefore, whether a study abroad program is relevant to a student's degree plan would be one of the factors in this category (Carlson et al., 1991). The perceived complexity of participating in a study abroad program is also likely to be an influencing factor (Spiering and Erickson, 2006). Students will be discouraged from study abroad if they see the process as too complicated (in terms of the signingup process, meeting of eligibility requirements, obtaining necessary visas, etc.) or if going on study abroad could delay graduation. On the other hand, students will be motivated to participate if they see the process as simple. Other factors in the general perceptions category would be the extent of enjoyment expected from the trip, the possibility of meeting interesting people, sightseeing, etc. (Carsello and Creaser, 1976; McKeown, 2009).

\section{Intercultural Awareness}

Intercultural awareness enables students to understand and adapt to cultures other than their own (Bennett, 2004). Study abroad programs are expected to foster learning and understanding of hitherto unfamiliar host country cultures (Spradley, 1979). Communicating with culturally different individuals is a key feature (Goldstein and Kim, 2006). Study abroad can provide students with a cultural immersion through experiential learning when students live in local accommodations, eat local food, interact with local professors and students, and learn local customs. Therefore, study abroad can offer the students much more than just a descriptive exposure to other cultures (Jones, 2003) and can enhance intercultural competence in students, which is described as "a developmental process of personal maturation whereby the learner evolves from lower to higher levels of intercultural awareness (Koskinen and Tossavainen, 2004, p.112)." This is likely to result in improved global perspective and world-mindedness in students and better preparedness for a globalized workplace (Carlson and Widaman, 1988).

Besides improving the students' ability to understand and adapt to other cultures, Study abroad programs can also help in improving the students' understanding of their own culture by comparing it with the host culture and looking at it from the outside (Ingraham and Peterson, 2004). Students can then become more aware of their own national identities (Dolby, 2004). For all these potential benefits, intercultural awareness is a primary goal of participating in study abroad programs (Yang, Webster, and Prosser, 2011).

\section{Personal Growth}

Personal growth refers to the increased confidence and self-reliance likely to be instilled in study abroad program participants (Pyle, 1981). These qualities increase the students' leadership skills, problem-solving skills, ability to cope with unfamiliar and ambiguous situations, and open-mindedness (Ingraham and Peterson, 2004; Lindsey, 2005; Black and Duhon, 2006). A study abroad program teaches students to take responsibility for their own decisions as they are away from direct family contact and cannot rely on other adults to make decisions for them (Hadis, 2005). Such independence is a trait of maturity and is an expected outcome of participating in a study abroad program.

\section{Professional Development}

Professional development involves the choice of career, the development of the awareness of how a student's intended profession may be viewed and practiced differently in different cultures, and the acquisition of attitudes and cross-cultural skills that help a person to be an effective professional (Dwyer, 2004). The literature suggests that participation in study abroad programs often confirms the career choice a student has already made, while at other times it makes students change fields or narrow their choices (Ingraham and Peterson, 2004; Norris and Gillespie, 2009). Career development is a significant reason for students to participate in study abroad programs (Carlson et al., 1990). Exposure to foreign environments is likely to make study abroad participants more attractive for employment by multinational corporations (Hannigan, 2001). In terms of the long-term impact on study abroad participants' professional development, the majority of respondents in a survey (Franklin, 2010) taken ten years after graduation strongly agreed or agreed that their study abroad experience played a role in their professional success and also influenced their sense of professional ethics. 


\section{Intellectual Growth}

Expected intellectual growth from a study abroad program has two dimensions: language learning and academic performance (Ingraham and Peterson, 2004). Learning and gaining proficiency in a foreign language is a major objective for many study abroad participants (Paige et al., 2002). Ashwill (2004) has argued that the best way to acquire foreign language proficiency is to surround oneself with indigenous people who regularly speak the native language. A combination of immersion in the native speech community and formal classroom learning creates the best environment for learning a second language (Freed, 1998). As for academic performance, various studies have indicated that study abroad participants develop sophisticated cognitive skills (McKeown, 2009), achieve better grade point averages (Sutton and Rubin, 2004), and progress toward graduation more quickly (Flash, 1999).

\section{Duration And Cost}

The Institute of International Education (2013) has classified study abroad programs in terms of duration into three categories: short term (summer, or eight weeks or less), mid-length (one or two quarters or one semester), and long-term (academic or calendar year). Programs of shorter duration have traditionally enjoyed higher participation rates. In 2011-12, 58.9\% of all American study abroad students participated in short-term programs, $37.9 \%$ participated in mid-length programs, and only $3.2 \%$ participated in long-term programs. Financial constraints faced by students and their families are a major reason for the greater popularity of short-term programs (Mills, Deviney, and Ball, 2010), which cost less than long-term programs.

\section{Demographic Factors}

There have been consistent disparities among study abroad participants across race, gender, and academic majors (Salisbury et al., 2009). Ethnic minorities have been underrepresented among study abroad participants for many years (Desoff, 2006). The National Center for Education Statistics (2013) reported that $77.8 \%$ of American study abroad students in 2010-11 were white, while just $61.2 \%$ of all full-time post-secondary students in the United States during the same year were white. In comparison, the representation percentages of whites among study abroad participants and full-time post-secondary students in the year 2000-2001 were $84.3 \%$ and $70.8 \%$, respectively. Thus, while the proportion of minority students studying abroad increased by only $6.5 \%$, the proportion of minority students enrolled in higher education increased by a full $10 \%$ over the same period. There has also been a long-standing gender gap among American study abroad participants (Salisbury, Paulsen, and Pascarella, 2010). Females outnumbered males consistently by a ratio of 65:35 in participating in study abroad programs during the ten year period between 2000-01 and 2010-11 (National Center for Education Statistics, 2013). A major reason for this gender gap is the fact that over one-third of American study abroad students belong to social sciences and humanities majors (Institute of International Education, 2013), fields that have been traditionally dominated by females. Among other fields of study, business and engineering contributed $20.5 \%$ and $3.9 \%$ of study abroad students from the United States in 2011-12 (Institute of International Education, 2013). Therefore, the demographic profile of the typical American study abroad student would be white, female, and pursuing a social science/humanities major.

\section{Intention To Participate}

Students' intentions to participate in a study abroad program is the dependent variable in the framework. According to the Theory of Planned Behavior (Ajzen, 1991), expressed intention to participate is the best indicator of actual participation.

\section{PROPOSITIONS} offered:

Based on the preceding discussion of the framework in Figure 1, the following theoretical propositions are

P1: Students' positive general perceptions (e.g., relevance to degree plan, enjoyment, sightseeing) about study abroad programs are positively related to their expectations of personal growth, professional development, 
and intellectual growth from such programs.

P2: $\quad$ Students' negative general perceptions (e.g., complexity of the process) about study abroad programs are negatively related to their expectations of personal growth, professional development, and intellectual growth from such programs.

P3: Students' expectations of gaining intercultural awareness from study abroad programs are positively related to their expectations of personal growth, professional development, and intellectual growth from such programs.

P4: Students' expectations of personal growth from study abroad programs are positively related to their intention to participate in such programs.

P5: Students' expectations of professional development from study abroad programs are positively related to their intention to participate in such programs.

P6: Students' expectations of intellectual growth from study abroad programs are positively related to their intention to participate in such programs.

P7: The duration and cost of study abroad programs are negatively related to students' intentions to participate in such programs.

\section{IMPLICATIONS}

The conceptual framework has important implications for college counselors and study abroad program directors who seek to increase student participation in the programs. Once the program directors identify the expectations that students have from studying abroad, they can further cultivate these factors.

First, the general perceptions held by students about studying abroad must be positive. Students need to be convinced that a study abroad program would be relevant to their major field. As stated earlier, study abroad programs have been historically dominated by social sciences and humanities majors. More effort is needed to improve participation among physical science and pre-professional majors. This could be achieved by introducing more short-term study abroad programs (Salisbury, Paulsen, and Pascarella, 2010).

Increasing participation from majors other than social sciences and humanities could also help close the gender gap, since these majors tend to attract predominantly female students. As for increasing minority participation, in particular, and overall participation, in general, the financial constraints need to be eased (Hembroff and Rusz, 1993). Greater availability of financial aid and scholarship would ease the financial burden and attract more participants (Naffziger, Bott, and Mueller, 2008). Offering more short-term programs, typically at lower cost, should also help in this regard.

Efforts need to be made to alleviate any student concerns about the complexity of the participation process. Assistance needs to be given in making pre- and during-trip arrangements, such as obtaining necessary visas, travel, accommodations, etc. In addition, the "fun" aspects of going on a study abroad trip, such as enjoying friends, meeting new people, and sightseeing, should also be emphasized.

Addressing the expectations regarding intercultural awareness comes next. Improving intercultural competence through intercultural awareness is a pivotal benefit that can be derived from study abroad programs. Students who have little international travel experience may suffer from intercultural communication apprehension, which is the anxiety associated with real or anticipated interaction with others of different cultural backgrounds than oneself (Neuliep and McCrosky, 1997). A high level of intercultural communication apprehension will have a negative impact on students' intentions to participate in study abroad, so college advisors must try to allay such apprehension and focus on the positive outcomes of intercultural awareness (such as understanding of international issues, appreciation of human differences, understanding of one's own culture, ability to function in a multicultural workplace, etc.) instead.

Creating positive expectations of intercultural awareness will help in creating positive expectations of outcomes regarding students' personal growth, professional development, and intellectual growth. If students understand that participating in study abroad will make them more self-reliant, will develop their leadership skills, will help them find professional direction, will make them more proficient in foreign languages, and will help in 
their academic performance, then they will be more likely to participate. The reinforcement of positive beliefs about study abroad needs to be made at multiple levels — it should not involve just college counselors/administrators - but should also involve faculty (particularly those who lead students to study abroad trips), parents, and other influential guardians. Such involvement will help build the "cultural capital" that will make students more predisposed to participate in study abroad (Salisbury et al., 2009).

\section{CONCLUSION}

This paper presents a conceptual framework to identify and investigate the factors that influence college students to participate in study abroad programs. The authors subscribe to the idea that expectations are crucial to a student's initial decision to be a participant in a study abroad program (Goldstein and Kim, 2006). It is posited that expectations regarding personal growth, professional development, and intellectual growth will directly impact the intent to participate, while these expectations will be influenced, in turn, by the expectations of intercultural awareness and certain general perceptions about study abroad that students may have. Program cost and duration, as well as demographic factors, such as race and gender, will also play a role in determining the intention to participate.

The number of American college students participating in study abroad has increased from 241,791 in 2006-07 to 283,332 in 2011-12, an increase of 17.2\% over the five-year period (Institute of International Education, 2013). Considering that just 89,242 students participated in study abroad in 1995-96, the increase to 2011-12 is over 200 percent. Still, only $1.4 \%$ of all American college students participated in study abroad at the latest count. The Lincoln Commission (2005) set a goal of American undergraduate study abroad participation at one million by the year 2017. In 2007, the U.S. Congress allocated an additional $\$ 80$ million per year for study abroad scholarships (Salisbury et al., 2009). In order to come even close to meeting the one million student goal by 2017, the number of participants needs to increase drastically from current levels. To make this happen, more effective marketing of study abroad programs is necessary. Following the framework described in this paper, developing and implementing programs that provide students with positive and accurate expectations of study abroad is likely to be a useful approach.

\section{AUTHOR INFORMATION}

Dr. Soumava Bandyopadhyay is a professor of marketing and a Jerry and Sheila Reese Faculty Scholar in Business at Lamar University, U.S.A. His areas of research interest include Internet-based marketing, global marketing, and channels of distribution. He has traveled to over 50 countries and has also led a group of MBA students on a study abroad trip to China. E-Mail: soumava.bandyopadhyay@lamar.edu.

Dr. Kakoli Bandyopadhyay is a professor of management information systems and Chair of the Information Systems and Analysis department at Lamar University, U.S.A. Her research interests include the use of business intelligence for competitive advantage, user acceptance of ERP systems, academic honesty in online courses, and college study abroad programs. E-Mail: kakoli.bandyopadhyay@lamar.edu.

\section{REFERENCES}

Ashwell, M. A. (2004). Developing Intercultural Competence for the Masses. International Educator, 13 (2), $16-25$. Ajzen, I. (1991). The Theory of Planned Behavior. Organizational Behavior and Human Decision Processes, 50 (2), $179-211$.

Bennett, M. J. (2004). Becoming Culturally Competent. In J. Wurzel (ed.), Toward Multiculturism: A Reader in Multicultural Education, $2^{\text {nd }} E d$., Newton, MA: Intercultural Resources Corporation, 62-77.

Black, H. T., \& Duhon, D. L. (2006). Assessing the Impact of Business Study Abroad Programs on Cultural Awareness and Personal Development. Journal of Education for Business, 81 (3), 140-144.

Carlson, J. S., Burn, B. B., Useem, J., \& Yachimowicz, D. (1990). Study Abroad: The Experience of American Undergraduates. Westport, CT: Greenwood.

Carlson, J. S., Burn, B. B., Useem, J., \& Yachimowicz, D. (1991). Study Abroad: The Experience of American Undergraduates in Western Europe and the United States. New York: Council on International Educational Exchange. 
Carlson, J. S., \& Widaman, K. F. (1988). The Effects of Study Abroad During College on Attitudes Towards Other Cultures. International Journal of Intercultural Relations, 12 (1), 1-18.

Carsello, C., \& Creaser, J. (1976). How College Students Change During Study Abroad. College Student Journal, $10,276-278$.

de Jong, P., Schnusenberg, O., \& Goel, L. (2010). Marketing Study Abroad Programs Effectively: What do American Business Students Think? Journal of International Education in Business, 3 (1/2), 34-52.

Desoff, A. (2006). Who's Not Going Abroad? International Educator, 15 (2), 20-27.

Dolby, N. (2004). Encountering an American Self: Study Abroad and National Identity. Comparative Education Review, 48 (2), 150-173.

Dwyer, M. M. (2004). More is Better: The Impact of Study Abroad Program Duration. Frontiers: The Interdisciplinary Journal of Study Abroad, 10, 151-163.

Flash, S. J. (1999). Study Abroad Program Participation: Effects on Academic Progress. Doctoral Dissertation, State University of New York at Buffalo.

Franklin, K. (2010). Long Term Career Input and Professional Applicability of the Study Abroad Experience. Frontiers: The Interdisciplinary Journal of Study Abroad, 19, 169-190.

Freed, B. (1998). An Overview of Issues and Research in Language Learning in a Study Abroad Setting. Frontiers: The Interdisciplinary Journal of Study Abroad, 4, 31-60.

Goldstein, S. B., \& Kim, R. I. (2006). Predictors of U.S. College Students' Participation in Study Abroad Programs: A Longitudinal Study. International Journal of Intercultural Relations, 30 (4), 507-521.

Hadis, B. F. (2005). Why Are They Better Students When They Come Back? Determinants of Academic Focusing Gains in the Study Abroad Experience. Frontiers: The Interdisciplinary Journal of Study Abroad, 11, 5770.

Hannigan, T. R. (2001). The Effect of Work Abroad Experience on Career Development for U.S. Undergraduates. Frontiers: The Interdisciplinary Journal of Study Abroad, 7, 1-23.

Hembroff, L. A., \& Rusz, D. L. (1993). Minorities and Overseas Studies Programs: Correlates of Differential Perceptions. New York: Council on International Educational Exchange.

Horn, A., \& Fry, G. W. (2013). Promoting Global Citizenship Through Study Abroad: The Influence of Program Destination, Type, and Duration on the Propensity for Development Volunteerism. VOLUNTAS: International Journal of Voluntary and Nonprofit Organizations, 24 (4), 1159-1179.

Ingraham, E., \& Peterson, D. L. (2004). Assessing the Impact of Study Abroad on Student Learning at Michigan State University. Frontiers: The Interdisciplinary Journal of Study Abroad, 10, 83-100.

Institute of International Education [IIE]. (2013). Open Doors Report, 2013. Retrieved from http://opendoors.iienetwork.org.

Jones, W. H. (2003). Over the Wall: Experiences with Multicultural Literacy. Journal of Marketing Education, 25 (3), 231-240.

Kim, R., \& Goldstein, S. B. (2005). Intercultural Attitudes Predict Favorable Study Abroad Expectations of U.S. College Students. Journal of Studies in International Education, 9 (3), 265-278.

Koskinen, L., \& Tossavainen, K. (2004). Study Abroad as a Process of Learning Intercultural Competence in Nursing. International Journal of Nursing Practice, 10, 111-120.

Lincoln Commission (2005). Global Competence and National Needs: One Million Americans Studying Abroad. Final Report. Washington, DC: Commission on the Abraham Lincoln Fellowship Program.

Lindsey, E. W. (2005). Study Abroad and Values Development in Social Work Students. Journal of Social Work Education, 41 (2), 229-249.

McKewon, J. S. (2009). The First Time Effect: The Impact of Study Abroad on College Student Intellectual Development. Albany, NY: State University of New York Press.

Mills, L., Deviney, D., \& Ball, B. (2010). Short Term Study Abroad Programs: A Diversity of Options. Journal of Human Resource and Adult Learning, 6 (2), 1-13.

Naffziger, D. W., Bott, J. P., \& Mueller, C. B. (2008). Factors Influencing Study Abroad Decisions among College of Business Students. International Business: Research, Teaching and Practice, 2 (1), 39-52.

National Center for Education Statistics. (2013). Table 310.10. Number of U.S. Students Studying Abroad and Percentage Distribution by Sex, Race/Ethnicity, and Other Selected Characteristics; Selected Years 199697 Through 2010-11. U.S. Department of Education. Retrieved from http://nces.ed.gov.

Neuliep, J. W., \& McCrosky, J. C. (1997). The Development of Intercultural and Interethnic Communication Apprehension Scales. Communication Research Reports, 14, 145-156. 
Norris, E. M., \& Gillespie, J. (2009). How Study Abroad Shapes Global Careers: Evidence from the United States. Journal of Studies in International Education, 13 (3), 382-397.

Paige, R. M., Cohen, A. D., Kappler, B., Chi, J., \& Lassegard, J. P. (2002). Maximizing Study Abroad: A Students' Guide to Strategies for Language and Culture Learning and Use. Minneapolis, MN: Center for Advanced Research on Language Acquisition, University of Minnesota.

Pyle, K. R. (1981). International Cross-Cultural Service and Learning: Impact on Student Development. Journal of College Student Personnel, 22 (6), 509-514.

Salisbury, M. H., Paulsen, M. B., \& Pascarella, E. T. (2010). To See The World or Stay at Home: Applying an Integrated Student Choice Model to Explore the Gender Gap in the Intent to Study Abroad. Research in Higher Education, 51 (7), 615-640.

Salisbury, M. H., Umbach, P. D., Paulsen, M. B., \& Pascarella, E. T. (2009). Going Global: Understanding the Choice Process of the Intent to Study Abroad. Research in Higher Education, 50 (1), 119-143.

Spiering, K., \& Erickson, S. (2006). Study Abroad as Innovation: Applying the Diffusion Model to International Education. International Education Journal, 7 (3), 314-322.

Spradley, J. P. (1979). The Ethnographic Interview. New York: Holt, Rinehart, and Winston.

Sutton, R. C., \& Rubin, D. L. (2004). The GLOSSARI Project: Initial Findings from a System Wide Research Initiative on Study Abroad Learning Outcomes. Frontiers: The Interdisciplinary Journal of Study Abroad, 10, 65-82.

Tarrant, M. A., Rubin, D. L., \& Stoner, L. (2014). The Added Value of Study Abroad: Fostering a Global Citizenry. Journal of Studies in International Education, 18 (2), 141-161.

Yang, M., Webster, B., \& Prosser, M. (2011). Travelling a Thousand Miles: Hong Kong Chinese Students' Study Abroad Experience. International Journal of Intercultural Relations, 35 (1), 69-78.

Zemach-Bersin, T. (2007). Global Citizenship and Study Abroad: It's All About US. Critical Literacy: Theories and Practices, 1 (2), 16-28. 